\title{
Using vitellin monoclonal antibodies to assess the vitellogenesis-inhibiting hormone activity of Macrobrachium rosenbergii
}

\author{
Apiradee Sripiromrak, Parin Chaivisuthangkura, Siwaporn Longyant, Paisarn Sithigorngul \\ Department of Biology, Faculty of Science, Srinakharinwirot University, Bangkok 10110 Thailand \\ *Corresponding author, e-mail: paisarn@swu.ac.th, paisarn_sithi@ hotmail.com
}

Received 24 Jun 2013

Accepted 2 Mar 2014

\begin{abstract}
Vitellogenesis in crustaceans is under the inhibitory regulation of the endocrine system in the X-organ/sinus gland complex in the eyestalks. In this study, two monoclonal antibodies specific to Macrobrachium rosenbergii vitellin and vitellogenin were generated to assess vitellogenesis-inhibiting hormone (VIH) activity. A combination of two monoclonal antibodies specific to the 89 and $100 \mathrm{kDa}$ subunits of vitellin were used to develop a competitive enzyme-linked immunosorbent assay protocol for the quantitative determination of vitellogenin levels in haemolymph. Injection of eyestalk extracts from $M$. rosenbergii dissolved in either saline or in methanol-acetic acid caused a reduction in vitellogenin levels in the haemolymph at 12 and $24 \mathrm{~h}$ post-injection in bilateral eye-ablated prawns with developing ovaries. In contrast, the application of the heterologous eyestalk extract from Penaeus vannamei did not reduce vitellogenin levels in haemolymph. This assay is therefore specific and could be used to assess VIH activity during hormone purification.
\end{abstract}

KEYWORDS: competitive ELISA, eyestalk, crustacean

\section{INTRODUCTION}

Vitellogenesis in crustaceans is an important physiological process associated with female reproduction because vitellin provides the nutritive material necessary for the development of the embryo. During vitellogenesis, vitellogenin, the precursor of the major yolk protein vitellin, is synthesized in the ovary ${ }^{1-3}$ and in extra-ovarian tissues such as the hepatopancreas ${ }^{4,5}$. Regardless of its origin, vitellogenin is transported to the oocyte via the haemolymph and internalized into the oocyte through receptor-mediated endocytosis ${ }^{6,7}$. In the oocyte, vitellogenin is sequestered and modified into vitellin. Thus the synthesis of yolk proteins would be a good indicator of female reproductive activity in many crustacean species ${ }^{8}$. Vitellogenin concentrations in the haemolymph are correlated with ovarian morphological changes; vitellogenin concentrations increase during ovarian development and reach their greatest concentration prior to maximum yolk accumulation in oocytes, then decrease markedly prior to ovulation and spawning ${ }^{9-11}$.

Vitellogenin synthesis is under the inhibitory regulation of the neuroendocrine system, which is centred in the X-organ/sinus gland complex in the paired eyestalks in crustaceans. The X-organ/sinus gland complex secrets several neuropeptide hormones, such as vitellogenesis inhibiting hormone or gonad inhibiting hormone (VIH or GIH), molt-inhibiting hormone $(\mathrm{MIH})$, and crustacean hyperglycaemic hormone $(\mathrm{CHH})$, that are included in $\mathrm{CHH} / \mathrm{MIH} / \mathrm{VIH}$ family (reviewed by Huberman ${ }^{12}$ and Hopkins ${ }^{13}$ ). VIH has been purified and characterized in only two species, the American lobster Homarus americanus (Hoa-VIH) ${ }^{14}$ and the terrestrial isopod $\mathrm{Ar}$ madillidium vulgare $(\text { Arv-VIH })^{15}$. VIH from both species consists of 77 amino acid residues with a free C-terminus similar to molt-inhibiting hormone (MIH). Subsequently, cDNAs encoding VIH-like peptides from the Norway lobster Nephrops norvegicus (NenVIH) ${ }^{16}$, Metapenaeus ensis (Mee-MIH) ${ }^{17}$ and Macrobrachium rosenbergii (Mar-SPG-A) ${ }^{18}$ were identified. The vitellogenesis-inhibiting activity of these peptides however has not yet been characterized; therefore, it is still unclear which molecules are truly VIHs. The cDNA cloning results revealed that the Hoa-VIH ${ }^{19}$, Nen-VIH, Mee-MIH, and Mar-SGP-A precursors had an amidating signal sequence at the C-terminal end similar to $\mathrm{CHH}$. Experiments testing the ability of recombinant Hoa-VIH (rHoa-VIH) with either a 
free carboxy terminus or an amidated C-terminus to suppress vitellin mRNA levels in the ovarian fragment of Marsupenaeus japonicus revealed that the rHoa-VIH amide significantly reduced vitellogenin mRNA levels in the ovary, whereas rHoa-VIH-OH had no effect. The rHoa-VIH amide however showed very low vitellogenesis-inhibiting activity compared to the natural sinus gland extracts from Marsupenaeus japonicus, which may be due to the use of a heterologous bioassay or the presence of another $\mathrm{VIH}^{20}$. In recent studies, silencing of GIH expression in Penaeus monodon using GIH-specific double stranded RNA (GIH-dsRNA) increased the expression level of vitel$\operatorname{logenin}^{21,22}$. In a subsequent study, single injection of GIH-dsRNA into previtellogenic female P. monodon led to ovarian maturation and spawning in some prawn indicating that this method was still less effective than unilateral eyestalk ablation ${ }^{23}$.

Dynamic levels of vitellogenin in the haemolymph were observed during reproductive activities. Determination of mRNA expression and vitellogenin levels during ovarian maturation in $M$. rosenbergii demonstrated a close correlation ${ }^{24}$. A determination of the changes of haemolymph vitellogenin levels could therefore be used to assess the action of the hormone directly ${ }^{10,11}$. The giant freshwater prawn $M$. rosenbergii is commercially farmed in the central part of Thailand. Due to its large size, high abundance, ease of culture and normal ovarian maturation under farm and laboratory conditions, this species is an ideal model for reproductive studies. In this study, monoclonal antibodies specific to subunits of $M$. rosenbergii vitellin and vitellogenin were generated and used for the development of a competitive ELISA assay for the quantitative determination of changes in vitellogenin levels in the haemolymph; our aim was to develop an assay for the VIH activity in the eyestalk of M. rosenbergii.

\section{MATERIALS AND METHODS}

\section{Source, animal handling, and initial preparation}

Adult female (20-30 g) and adult male (100-150 g) freshwater prawns (M. rosenbergii) were purchased from farms in the northern part of Bangkok, Thailand. The prawns were maintained at ambient photoperiod in freshwater cement tanks $(\mathrm{w} \times 1 \times \mathrm{h}$ : $100 \times 250 \times 50 \mathrm{~cm}$ ) with water temperatures of 26 $28^{\circ} \mathrm{C}$. They were fed commercial shrimp food pellets in the morning and evening, and half of the water was changed every 2 days.

Penaeus vannamei (15-20 g) were purchased from farms in nearby Bangkok. They were maintained in $10 \mathrm{~g} / \mathrm{l}$ diluted seawater and treated in the same manner as $M$. rosenbergii.

Six weeks old female Swiss mice were purchased from the National Laboratory Animal Centre of Mahidol University, Salaya, Nakhon Pathom, Thailand. They were maintained under conventional hygienic conditions, and all procedures involving laboratory animals were conducted according to the guidelines issued by the National Committee on Laboratory Animals, the National Research Council, Thailand (Protocol no. 125/2553, February 2010).

\section{Ovarian extract and haemolymph preparations}

Five female $M$. rosenbergii with gravid ovaries were anaesthetized using cold water $\left(4^{\circ} \mathrm{C}\right)$, and haemolymph was collected via the arthrodial membrane of the fourth walking leg and stored at $-20^{\circ} \mathrm{C}$ until use. Ovaries were removed by dissection and washed in cold 0.15 M phosphate-buffered saline (PBS), pH 7.4. The ovaries were homogenized in $0.5 \mathrm{mM}$ EDTA in PBS $(0.5 \mathrm{~g} / \mathrm{ml})$. The pellet and lipid layer were removed after centrifugation at $5000 \mathrm{~g}$ at $4{ }^{\circ} \mathrm{C}$ for $10 \mathrm{~min}$. The protein concentration of the ovarian extract was determined by Bradford assay ${ }^{25}$, and the purity was determined by sodium dodecyl sulphate polyacrylamide gel electrophoresis (SDS-PAGE). The protein concentration was adjusted to $20 \mathrm{mg} / \mathrm{ml}$ in PBS, and the extract was divided into $1 \mathrm{ml}$ aliquots and stored at $-70^{\circ} \mathrm{C}$.

Haemolymph samples from both female $M$. rosenbergii with developing ovaries and male $M$. rosenbergii was collected and stored in the same fashion.

\section{Immunization}

The ovarian extract $(1 \mathrm{mg} / \mathrm{ml})$ was mixed with complete Freund's adjuvant at a ratio of 1:1 and was intraperitoneally injected into four Swiss mice (100 $\mu \mathrm{l} /$ mouse). The mice were then boosted with the ovarian extract mixed with incomplete Freund's adjuvant three times at two week intervals. One week after the fourth injection, mouse anti-vitellin antisera were collected and tested against ovarian extract and female and male haemolymph by Western blotting. The mouse that produced the strongest response was boosted three days before hybridoma production.

\section{Hybridoma production}

A cell fusion procedure was adapted from the reported protocol $^{26}$. The P3X myeloma cell line was used as the fusion partner. Fusion products from one mouse were plated on 20 microculture plates (96 wells). After identifying wells containing the desired clones by the dot blotting and Western blotting methods, the 
cells were cloned at least twice by the limiting dilution $\operatorname{method}^{27}$.

\section{Screening methods}

Hybridoma cell lines were first screened by dot blotting. Ovarian extract $(0.1 \mathrm{mg} / \mathrm{ml})$ and male haemolymph were applied to $96 \times 20$ pieces of nitrocellulose membrane. After the membrane was heated at $60^{\circ} \mathrm{C}$ for $10 \mathrm{~min}$, each piece was incubated in hybridomaconditioned medium ${ }^{28}$ from each well (1:8 in 5\% blotto $=5 \%$ non-fat dry milk in PBS) at $37^{\circ} \mathrm{C}$ for $5 \mathrm{~h}$. After extensive washing in PBS, antibody binding was detected using horseradish peroxidase-labelled goat anti-mouse heavy and light-chain-specific IgG (GAM$\mathrm{HRP}$ ) at a $1: 1500$ dilution at $37^{\circ} \mathrm{C}$ for $3 \mathrm{~h}$. The membrane was then washed as described previously and applied to a substrate mixture $(0.03 \%$ diaminobenzidine, $0.006 \%$ hydrogen peroxide, $0.05 \%$ cobalt chloride in PBS) for 5 min. Hybridoma clones that demonstrated a strong positive result with the ovarian extract and a negative result with male haemolymph were selected for further screening by dot blotting and Western blotting against female haemolymph, male haemolymph and ovarian extract. SDS-PAGE was performed in slab gels in a mini-PROTEIN II electrophoresis apparatus (Bio-Rad) to identify vitellin and vitellogenin in the extract. Ovarian extract and female and male haemolymph were applied to a $12 \%$ gel, which was run at 80 volts for $2 \mathrm{~h}$. Part of the gel was cut off and visualized by staining with $0.1 \%$ Coomassie brilliant blue R250. Proteins in other parts of the gel were transferred to a nitrocellulose sheet using the Transblot apparatus (Bio-Rad) at 50 volts for $3 \mathrm{~h}$. The nitrocellulose sheet was then separated from the gel and quenched in 5\% blotto, cut into strips and incubated in the hybridoma-conditioned media from the first screen (1:100 in $1 \%$ blotto) at $37^{\circ} \mathrm{C}$ for $5 \mathrm{~h}$. After extensive washing in PBS, the membrane was assayed as in dot blotting described above.

The selected hybridoma clones that bound with the ovarian extract and the female haemolymph but not the male haemolymph were re-cloned and cryopreserved for further characterization ${ }^{29}$.

\section{Detection of monoclonal antibody sensitivity by dot blotting}

Two-fold serial dilutions of ovarian extract and female (1 $\mathrm{mg} / \mathrm{ml})$ and male haemolymph were diluted in PBS. All antigens ( $1 \mu \mathrm{l} / \mathrm{spot})$ were applied to pieces of nitrocellulose membrane. After the membrane was blocked in $5 \%$ blotto for $5 \mathrm{~min}$, each piece was assayed for dot blotting using each MAb as described above.

\section{Detection of monoclonal antibody titre by indirect immunoperoxidase ELISA}

The optimal titre of monoclonal antibody for the development of competitive enzyme-linked immunosorbent assay (ELISA) was determined by indirect immunoperoxidase ELISA as follows: a 96-well Maxisorb microtitre plate (NUNC) was coated for overnight incubation with $50 \mu \mathrm{l} /$ well of ovarian extract $(1 \mu \mathrm{g} / \mathrm{ml})$ in $0.15 \mathrm{M}$ phosphate-buffered saline, $\mathrm{pH} 7.4$ (PBS), at $4{ }^{\circ} \mathrm{C}$. Blotto was used as a blocking solution, antibody diluent and washing solution. The two-fold serial dilution of the highest avidity MAbs for each vitellin subunit was added into the wells. The plate was then incubated at $4{ }^{\circ} \mathrm{C}$ for $6 \mathrm{~h}$. Monoclonal antibody binding to the plates was detected using GAM-HRP at a 1:1000 dilution. After washing, $100 \mu \mathrm{l}$ of the substrate mixture consisting of $0.1 \%$ o-phenylenediamine and $0.006 \% \mathrm{H}_{2} \mathrm{O}_{2}$ in $0.1 \mathrm{M}$ citrate buffer ( $\mathrm{pH} 4.5)$ was added to each well. After 5 min incubation, $100 \mu \mathrm{l}$ of $1 \mathrm{M} \mathrm{H}_{2} \mathrm{SO}_{4}$ was added to each well to stop the reaction. The plate was read at $490 \mathrm{~nm}$ on a microplate reader. The dilution (titre) of the MAb that gave a submaximal OD was used in the competitive ELISA for vitellogenin determination.

\section{Validation of competitive ELISA}

The Maxisorb microtitre plate was prepared as described above. $M$. rosenbergii ovarian extract, haemolymph from females with developing ovaries or male haemolymph were serially diluted in $5 \%$ blotto and added $(50 \mu \mathrm{l} /$ well $)$ to each row of the plate. Then $50 \mu \mathrm{l}$ of the diluted MAb (at submaximal OD) was added to each well. The plate was incubated at $4{ }^{\circ} \mathrm{C}$ for $6 \mathrm{~h}$ and processed by indirect immunoperoxidase as described above. Similarity between vitellin and vitellogenin and the limited detection of each MAb was determined from the graph of OD against antigen dilutions.

The intra-assay and inter-assay variations were tested using vitellin spiked into male haemolymph (diluted 1:10 in PBS) at low $(2 \mu \mathrm{g} / \mathrm{ml})$ and high concentrations $(10 \mu \mathrm{g} / \mathrm{ml})$ for 10 replicates.

\section{Preparation of crude eyestalk extract in M-saline}

Eyestalks were excised from live adult female prawns with undeveloped ovaries, frozen immediately on dry ice and stored at $-70^{\circ} \mathrm{C}$ until use. Eyestalks were dissected to remove the outer shell and the pigment in retina while partially thawed; then, the eyestalks were immediately homogenized in M-saline ( $M$. rosenbergii isotonic physiological saline, $\mathrm{pH} 7.6^{30}$ ) with a glass homogenizer $(0.5 \mathrm{ml} /$ eyestalk $)$. After centrifu- 
gation at $10000 \mathrm{~g}$ at $4{ }^{\circ} \mathrm{C}$ for $30 \mathrm{~min}$, the pellet was re-extracted with M-saline. Supernatants from both extractions were pooled, and the volume was adjusted with $\mathrm{M}$-saline to 10 eyestalks $/ \mathrm{ml}$, divided into small aliquots and stored frozen at $-70^{\circ} \mathrm{C}$ until use ${ }^{11}$.

Eyestalk extract from $P$. vannamei was prepared in the same manner and used for testing the cross reactivity of VIH between the two species.

\section{Eyestalk extraction in methanol acetic acid}

The eyestalk extract was prepared following the method for the isolation of hyperglycaemic hormone from the eyestalks of $M$. rosenbergii ${ }^{31}$ with slight modifications. Briefly, eyestalks were dissected as described above and frozen immediately on dry ice. Then freeze-dried powder of the eyestalk was prepared by grinding the eyestalks in a mortar on dry ice. The powder was extracted in $90 \%$ methanol: $1 \%$ acetic acid: $9 \%$ water $(0.5 \mathrm{ml} /$ eyestalk $)$ at $4{ }^{\circ} \mathrm{C}$ for $24 \mathrm{~h}$. Tissue debris was removed by centrifugation at $10000 \mathrm{~g}$ for $15 \mathrm{~min}$. The supernatant was collected, and the pellet was re-extracted in the same medium. The supernatants from both extractions were combined and evaporated in a vacuum concentrator (Speed-vac, Savant, Farmingdale, NY) until free of methanol and acetic acid. A solution of $1 \%$ trifluoroacetic acid (TFA) was then added to the extract to achieve a final concentration of $0.1 \%$ TFA. The extract was passed through $\mathrm{C}_{18}$ Sep-Pak cartridges (Waters Associates, Milford, MA), the bound materials were eluted with $50 \%$ acetonitrile $/ 0.1 \%$ TFA, and $100 \mu \mathrm{l}$ of $10 \mathrm{mg} / \mathrm{ml}$ bovine serum albumin (BSA) was added to the solution at a ratio of 100 eyestalks $/ \mathrm{mg}$ of BSA. The eluate was evaporated in the vacuum concentrator to dryness and stored at $-70{ }^{\circ} \mathrm{C}^{31}$. The extract, equivalent to 10 eyestalks $100 \mu \mathrm{l}$, was redissolved in M-saline and aliquoted for the VIH assay.

\section{Effect of eyestalk extract in M-saline on haemolymph vitellogenin levels}

Ovarian development in $M$. rosenbergii was induced by bilateral eyestalk ablation. Two to three days after eye ablation, ten prawns with stage II developing ovaries (observed through the carapace) were used for each set of the experiment. Crude $M$. rosenbergii eyestalk extract in M-saline $(100 \mu \mathrm{l})$ was injected via the arthrodial membrane of the second walking leg at concentrations equivalent to $1 / 4,1 / 2,1$, and 2 eyestalks per prawn at 0 and $12 \mathrm{~h}$. The haemolymph $(100 \mu \mathrm{l})$ was collected from each prawn at 0,12 , and $24 \mathrm{~h}$ post injection (PI) and stored at $-20^{\circ} \mathrm{C}$ for vitellogenin analysis. The percentage of change in vitellogenin levels was calculated by subtracting the vitellogenin levels after injection at 12 or $24 \mathrm{~h}$ from the vitellogenin level at $0 \mathrm{~h}$ and dividing the result by the vitellogenin level at $0 \mathrm{~h}$.

The control experiment was performed by injecting the prawns with $100 \mu \mathrm{l}$ of $0.1 \mathrm{mg} / \mathrm{ml} \mathrm{BSA}$ in M-saline. The effect of the eyestalk extract in methanol acetic acid was determined in the same manner.

To determine the effect of eyestalk extract from other prawn species, crude eyestalk extract in M-saline from the penaeid prawn $P$. vanname $i$ was prepared in the same manner as that of $M$. rosenbergii and was injected into $M$. rosenbergii at concentrations of approximately 1 and 2 eyestalks/prawn. The changes in vitellogenin levels were determined as described above.

\section{Statistical analysis}

A multiple comparisons using ANOVA test using SPSS software (17.0 version, Inc. Chicago, USA) was utilized to examine the significance of differences among treatments; the means were compared using Duncan's multiple range test with $p<0.05$ as the significant level.

\section{RESULTS AND DISCUSSION}

\section{Ovarian extract preparation}

Ovarian extract prepared from the gravid ovary of M. rosenbergii demonstrated a high purity of vitellin as shown by SDS-PAGE. Only two major bands of vitellin subunits, at 89 and $100 \mathrm{kDa}$, were observed with trace amount of the other three protein bands when a high amount of ovarian extract was applied (Fig. 1a, lane 1). IMAGEJ software (http://rsbweb.nih. gov/ij/) analysis of the vitellin protein content percentage at $5 \mu \mathrm{g}$ protein revealed that the content of both vitellin subunits was over $95 \%$, and all light bands disappeared when half of the ovarian extract was loaded. This ovarian extract could therefore be used as a standard vitellin in comparison to vitellogenin in the haemolymph. In contrast, the major proteins in the haemolymph were two haemocyanin subunits, and the vitellogenin bands could not be visualized by Coomassie blue staining (Fig. 1a, lane 2).

\section{Production of monoclonal antibodies}

After the fourth immunization with ovarian extract, mouse antisera from four mice that had been preabsorbed with male haemolymph produced strong immunoreactivity to both subunits of vitellin and vitellogenin in female haemolymph but did not recognize any antigens in the male haemolymph. From one 


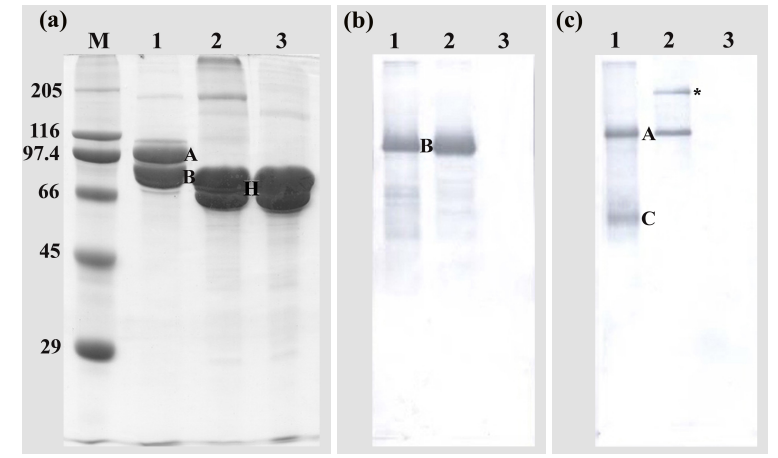

Fig. 1 SDS-PAGE and Western blot analysis of M. rosenbergii vitellin and vitellogenin. Ovarian extract (1) female haemolymph (2) and male haemolymph (3) were separated by SDS-PAGE and stained with Coomassie blue (a); proteins in other parts of the gel were transferred to a nitrocellulose membrane and immunoblotted with $\mathrm{MAb}$ specific to the (b) $89 \mathrm{kDa}$ (MRV 12C) and (c) $100 \mathrm{kDa}$ (MRV 14D) subunits. $M=$ molecular weight markers, $h=$ haemocyanin subunits, * labels the $170 \mathrm{kDa}$ vitellogenin precursor. The letters (A \& B) between lanes 1 and 2 are vitellin and vitellogenin subunits (molecular mass of 100 and $89 \mathrm{kDa}$, respectively). The letter (C) indicates putative degradation product of vitellin. Protein content was approximately $5 \mu \mathrm{g} / \mathrm{lane}$ of ovarian extract and $20 \mu \mathrm{g} / \mathrm{lane}$ of female and male haemolymph for Coomassie blue staining and approximately $0.05 \mu \mathrm{g} / \mathrm{lane}$ in ovarian extract for Western blotting.

fusion of spleen cells from the strongest response mouse, every well contained hybridoma colonies, ranging from 1-4 colonies/well in 20 microculture plates. In the first screening by dot blotting against ovarian extract and male haemolymph, approximately 100 wells were positive with varying immunoreactive intensity against ovarian extract only. The second screen of the strong immunoreactive wells was performed by dot blotting and Western blotting against ovarian extract, female haemolymph and male haemolymph. The six hybridoma clones producing antibodies that bound to the $89 \mathrm{kDa}$ subunit and the 12 hybridoma clones producing antibodies that bound to the $100 \mathrm{kDa}$ subunit were cloned to establish cell lines. The MAbs specific to the $89 \mathrm{kDa}$ subunit recognized only a higher-intensity band than that of the MAbs that recognized the $100 \mathrm{kDa}$ subunit in both the ovarian extract and the female haemolymph (Fig. 1b,c, lanes 1 and 2). The MAbs specific to the $100 \mathrm{kDa}$ protein also recognized a $170 \mathrm{kDa}$ protein in the female haemolymph; this protein is the precursor of the $100 \mathrm{kDa}$ protein ${ }^{32}$. However, only

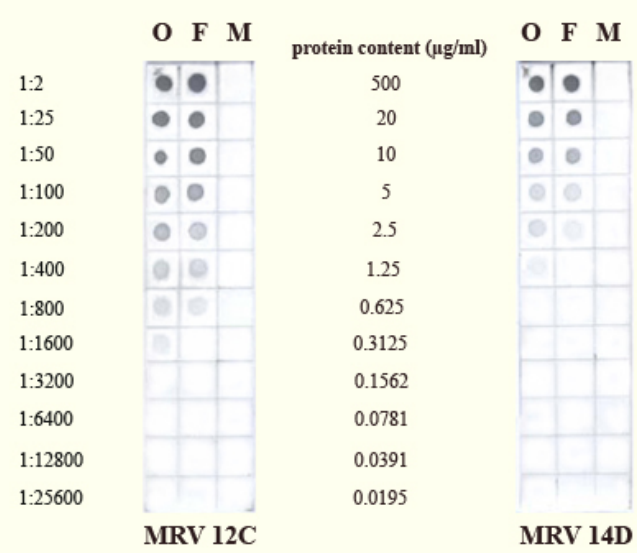

Fig. 2 Detection sensitivity of monoclonal antibodies specific for vitellin. MRV 12C and MRV 14D were tested against two-fold serial dilutions of ovarian extract $(\mathrm{O}$, initial protein concentration $1 \mathrm{mg} / \mathrm{ml}$ ), female haemolymph (F) and male haemolymph (M).

one MAb specific to the $89 \mathrm{kDa}$ subunit (MRV 12C) demonstrated the highest avidity to the ovarian extract at approximately $300 \mathrm{ng} / \mathrm{ml}$ ovarian extract, and one MAb specific to the $100 \mathrm{kDa}$ subunit (MRV 14D) demonstrated the highest avidity to the ovarian extract at approximately $1200 \mathrm{ng} / \mathrm{ml}$ ovarian extract (Fig. 2). Hence a mixture of these two MAbs (1:1) was selected for the development of competitive ELISA for the determination of vitellogenin in the haemolymph. Both MAbs belong to the IgG1 subclass with kappa light chains.

\section{Development of competitive ELISA for the quantitative analysis of vitellogenin}

For indirect ELISA using an ovarian extract-coated microtitre plate, the titres for the detection of vitellin at submaximal OD were 1:200 for MAb MRV 14D and 1:400 for MRV 12C. The combination of the two MAbs obtained similar results to the experiments that used each MAb separately. In competitive ELISA, the curves generated using either the ovarian extract or female haemolymph were superimposable (Fig. 3). This result demonstrated that the vitellogenin in female haemolymph is as effective as vitellin in inhibiting MAb binding to the vitellin adsorbed on the well. In contrast, male haemolymph had no competitive effect in the competitive ELISA assay. The range of vitellin that could be measured by this method was $0.8-20 \mu \mathrm{g} / \mathrm{ml}$. The intra-assay variations were in the range of $5-10 \%$ and inter-assay variations were lower, at approximately $4-8 \%$. 
Table 1 The change in haemolymph vitellogenin levels in eye-ablated $M$. rosenbergii after injection with saline or different eyestalk extract preparations at $12-24 \mathrm{~h}$.

\begin{tabular}{|c|c|c|c|c|c|c|c|}
\hline \multirow[t]{3}{*}{ Treatment } & \multirow{3}{*}{$\begin{array}{l}\mathrm{Vg} \text { levels at } \\
\text { the beginning } \\
\text { of the experi- } \\
\text { ment }(\mathrm{mg} / \mathrm{ml})\end{array}$} & \multicolumn{6}{|c|}{ Post injection Vg levels } \\
\hline & & \multicolumn{3}{|c|}{$12 \mathrm{~h}$} & \multicolumn{3}{|c|}{$24 \mathrm{~h}$} \\
\hline & & $\begin{array}{l}\text { Vg levels } \\
(\mathrm{mg} / \mathrm{ml})\end{array}$ & $\begin{array}{l}\text { Altered Vg levels } \\
(\mathrm{mg} / \mathrm{ml})\end{array}$ & $\%$ Change & $\begin{array}{l}\text { Vg levels } \\
(\mathrm{mg} / \mathrm{ml})\end{array}$ & $\begin{array}{l}\text { Altered Vg levels } \\
(\mathrm{mg} / \mathrm{ml})\end{array}$ & $\%$ Change \\
\hline M-saline & $0.88 \pm 0.77$ & $1.2 \pm 1.0$ & $0.28 \pm 0.29$ & $29 \pm 15^{a}$ & $1.4 \pm 1.2$ & $0.48 \pm 0.44$ & $57 \pm 26^{\mathrm{p}}$ \\
\hline \multicolumn{8}{|c|}{ Crude eyestalk extract of $M$. rosenbergii (E) in M-saline } \\
\hline $\begin{array}{l}\mathrm{E} 1 / 4 \\
\mathrm{E} 1 / 2 \\
\mathrm{E} 1 \\
\mathrm{E} 2\end{array}$ & $\begin{array}{l}0.90 \pm 0.87 \\
1.03 \pm 0.72 \\
1.10 \pm 0.78 \\
1.47 \pm 0.76\end{array}$ & $\begin{array}{l}1.10 \pm 0.98 \\
0.83 \pm 0.76 \\
0.74 \pm 0.58 \\
1.11 \pm 0.77\end{array}$ & $\begin{array}{r}0.21 \pm 0.77 \\
-0.20 \pm 0.18 \\
-0.36 \pm 0.34 \\
-0.37 \pm 0.32\end{array}$ & $\begin{array}{r}32 \pm 28^{\mathrm{a}} \\
-27 \pm 24^{\mathrm{b}} \\
-32 \pm 20^{\mathrm{b}} \\
-32 \pm 25^{\mathrm{b}}\end{array}$ & $\begin{array}{c}1.2 \pm 1.1 \\
0.60 \pm 0.56 \\
0.50 \pm 0.46 \\
0.62 \pm 0.47\end{array}$ & $\begin{array}{r}0.35 \pm 0.23 \\
-0.43 \pm 0.30 \\
-0.60 \pm 0.54 \\
-0.85 \pm 0.42\end{array}$ & $\begin{array}{r}55 \pm 32^{\mathrm{p}} \\
-45 \pm 22^{\mathrm{q}} \\
-55 \pm 23^{\mathrm{q}} \\
-62 \pm 15^{\mathrm{q}}\end{array}$ \\
\hline \multicolumn{8}{|c|}{ Crude eyestalk extract of $M$. rosenbergii from methanol acetic acid (M) extraction } \\
\hline $\begin{array}{l}\text { M2 } \\
\text { M2 } \\
\text { M3 } \\
\text { M5 } \\
\text { M10 }\end{array}$ & $\begin{array}{c}0.70 \pm 0.57 \\
1.32 \pm 0.87 \\
1.4 \pm 1.2 \\
1.6 \pm 1.7 \\
1.97 \pm 0.92\end{array}$ & $\begin{array}{c}0.75 \pm 0.64 \\
0.97 \pm 0.61 \\
1.06 \pm 0.87 \\
1.3 \pm 1.5 \\
1.41 \pm 0.86\end{array}$ & $\begin{array}{r}0.08 \pm 0.21 \\
-0.35 \pm 0.48 \\
-0.31 \pm 0.45 \\
-0.25 \pm 0.15 \\
-0.56 \pm 0.31\end{array}$ & $\begin{aligned} & 21 \pm 27^{\mathrm{a}, n_{6}} \\
- & 22 \pm 20^{\mathrm{b}, n_{4}} \\
- & 20 \pm 15^{\mathrm{b}} \\
- & 25 \pm 15^{\mathrm{b}} \\
- & 33 \pm 19^{\mathrm{b}}\end{aligned}$ & $\begin{array}{c}0.95 \pm 0.64 \\
0.85 \pm 0.49 \\
0.92 \pm 0.86 \\
0.9 \pm 1.3 \\
0.76 \pm 0.55\end{array}$ & $\begin{array}{r}0.28 \pm 0.13 \\
-0.47 \pm 0.48 \\
-0.45 \pm 0.43 \\
-0.62 \pm 0.45 \\
-1.21 \pm 0.57\end{array}$ & $\begin{aligned} & 60 \pm 32^{\mathrm{p}, n_{7}} \\
- & 29 \pm 10^{\mathrm{q}, n_{3}} \\
- & 34 \pm 16^{\mathrm{q}} \\
- & 52 \pm 22^{\mathrm{qr}} \\
- & 65 \pm 17^{\mathrm{r}}\end{aligned}$ \\
\hline \multicolumn{8}{|c|}{ Crude eyestalk extract of $P$. vannamei in M-saline (PVE) } \\
\hline $\begin{array}{l}\text { PVE1 } \\
\text { PVE2 }\end{array}$ & $\begin{array}{l}0.96 \pm 0.77 \\
1.00 \pm 0.61\end{array}$ & $\begin{array}{l}1.10 \pm 0.84 \\
1.36 \pm 0.81\end{array}$ & $\begin{array}{l}0.14 \pm 0.11 \\
0.36 \pm 0.23\end{array}$ & $\begin{array}{l}19 \pm 12^{\mathrm{a}} \\
35 \pm 19^{\mathrm{a}}\end{array}$ & $\begin{array}{l}1.33 \pm 0.93 \\
1.64 \pm 0.95\end{array}$ & $\begin{array}{l}0.38 \pm 0.27 \\
0.64 \pm 0.41\end{array}$ & $\begin{array}{l}48 \pm 28^{\mathrm{p}} \\
70 \pm 24^{\mathrm{p}}\end{array}$ \\
\hline
\end{tabular}

$\mathrm{Vg}=$ vitellogenin.

The numbers are the mean \pm S.D.

For each treatment, $n=10$, except in $\mathrm{M} 2$, where $n=k$ is indicated with $n_{k}$, which generated different responses.

The significant difference for each treatment was compared with the control treatment injected with M-saline, and different letters indicate significant differences $(p<0.05)$ among treatments.

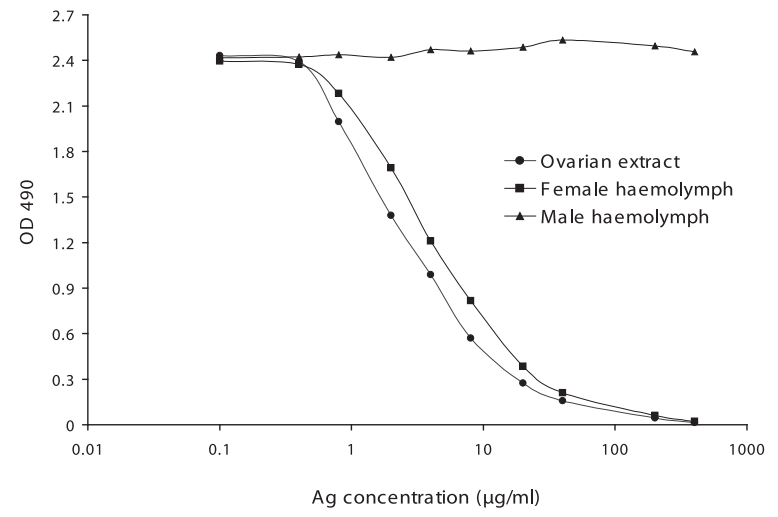

Fig. 3 Competitive ELISA of vitellin and vitellogenin. A combination of two MAbs specific to the two vitellin subunits, MRV 12C and MRV 14D, was used to detect the vitellin coated on the microtitre plate in competition with soluble antigens from ovarian extract (circles, initial protein concentration $1 \mathrm{mg} / \mathrm{ml}$ ), female haemolymph (squares), and male haemolymph (triangles). The antigens were diluted in the same patterns, and the concentrations of MRV $12 \mathrm{C}$ and MRV 14D were 1:400 and 1:200, respectively.

\section{Change in haemolymph vitellogenin levels in eye-ablated $M$. rosenbergii after the injection of $M$. rosenbergii eyestalk extract}

Two to three days after the ablation of the eyestalks from female prawns with resting ovaries, the prawn ovaries had reached stage II of development; ovaries at this stage can be observed through the carapace as having a light yellowish colour at the posterior portion of the ovary. Although the haemolymph vitellogenin levels at the beginning of the experiment varied from $0.2-3 \mathrm{mg} / \mathrm{ml}$ (average $0.7-1.9 \mathrm{mg} / \mathrm{ml}$, Table 1), in the control group (injection with saline), the levels of haemolymph vitellogenin in all prawns showed steady increases at $12 \mathrm{~h}$ PI and $24 \mathrm{~h}$ PI. In contrast, in the prawns injected with the eyestalk extract at a concentration equivalent to 1 eyestalk/prawn, the vitellogenin levels steadily decreased from the beginning levels both at $12 \mathrm{~h}$ PI and at $24 \mathrm{~h}$ PI (Fig. 4 and Table 1, M-saline and E1).

\section{Dose response}

When the amount of injected eyestalk extract was decreased to $1 / 2$ eyestalk equivalent, the decrease in vitellogenin levels was less than in those that received 1 eyestalk extract equivalent at both $12 \mathrm{~h} \mathrm{PI}$ and $24 \mathrm{~h}$ PI. The differences were however not statistically significant (Fig. 5). In contrast, in the prawns injected with $1 / 4$ eyestalk equivalent, the vitellogenin levels increased to levels similar to those observed in the control prawns at both $12 \mathrm{~h} \mathrm{PI}$ and $24 \mathrm{~h}$ PI (Fig. 5 and Table 1).

In the prawns injected with the eyestalk extract equivalent to 2 eyestalks, the reduction of haemolymph vitellogenin levels at $12 \mathrm{~h}$ PI were similar 


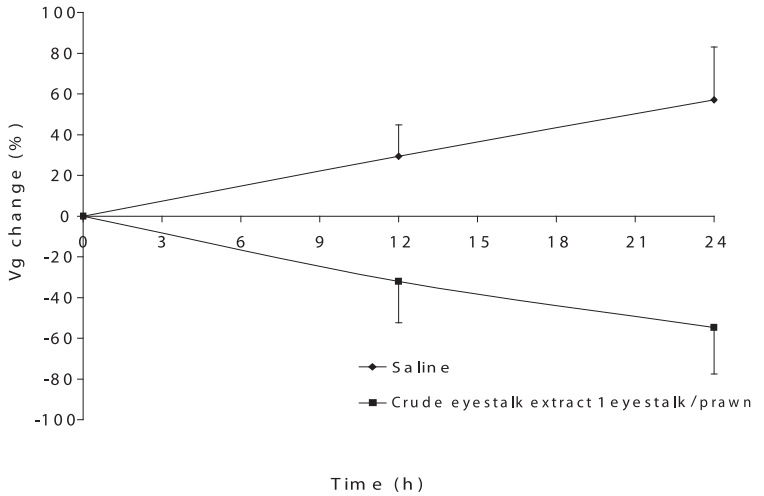

Fig. 4 The effects of crude eyestalk extract in M-saline on haemolymph vitellogenin levels. The changes in haemolymph vitellogenin levels in eye-ablated $M$. rosenbergii with developing stage II ovaries after injection of M-saline (diamonds) or eyestalk extract in M-saline (squares) were determined at 0,12 , and $24 \mathrm{~h}$ PI $(n=10)$.

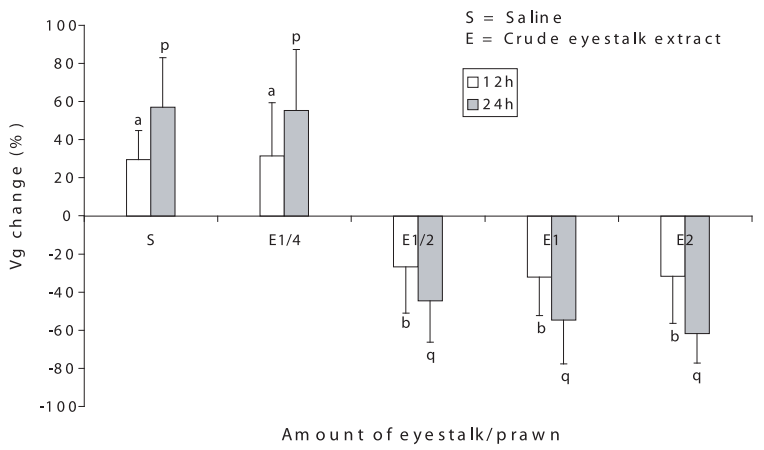

Fig. 5 The effects of different amounts of eyestalk extract on the change in haemolymph vitellogenin levels (number of sample, $n=10$ ). Bars are standard deviation. The different letters ( $a-b$ and $p-q)$ indicate the significant difference $(p<0.05)$ for vitellogenin levels at $12 \mathrm{~h}$ (white histogram) and $24 \mathrm{~h}$ (grey histogram), respectively. $S=$ saline and $E=$ crude eyestalk extract.

to that of the prawns injected with one eyestalk equivalent. At $24 \mathrm{~h}$, however, the reduction of haemolymph vitellogenin levels in the prawns receiving 2 eyestalk equivalents were slightly higher than that in the prawns receiving 1 eyestalk extract equivalent; however, the differences were not statistically significant (Fig. 5).

\section{The effect of the eyestalk extracted by methanol acetic acid on haemolymph vitellogenin levels}

In the prawns receiving 5-10 eyestalk extract equivalents obtained by methanol acetic acid (Fig. 6 and Table 1), we observed a decrease in the haemolymph

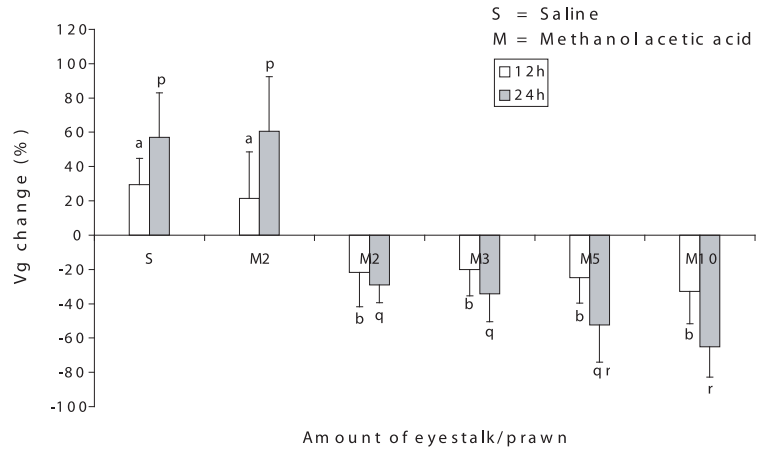

Fig. 6 The effects of eyestalk extract extracted by methanol acetic acid on the change in haemolymph vitellogenin levels at $12 \mathrm{~h}$ (white histogram) and $24 \mathrm{~h}$ (grey histogram), $(n=10)$ in all treatment except in M2, number of samples for each response indicated in parentheses. $S=$ saline and $M=$ methanol acetic acid extraction.

vitellogenin levels similar to the prawns that received the crude 1 and 2 eyestalk extract equivalents acquired by extraction in saline. The prawns treated with 3 eyestalk equivalents (M3) however had a slightly lower decrease in haemolymph vitellogenin levels, which was not significantly different at $12 \mathrm{~h}$ PI but was significantly different from M10 at $24 \mathrm{~h}$ PI. Surprisingly, among the prawns treated with 2 eyestalk equivalents (M2), 4 prawns showed a decrease in haemolymph vitellogenin similar to the prawns receiving 3 eyestalk equivalents, and 6 prawns showed an increase in haemolymph vitellogenin similar to that of the control prawn at $12 \mathrm{~h}$ PI. At $24 \mathrm{~h} \mathrm{PI}, 3$ of the M2 prawns showed a decrease and 7 showed an increase in haemolymph vitellogenin levels. The prawns receiving 3 acid methanol eyestalk equivalents yielded a pronounced and consistent effect of lowered haemolymph vitellogenin levels that was similar to the prawns receiving the $1 / 2$ eyestalk extract in the saline equivalent; therefore, the efficacy of methanol acetic acid extracts was estimated to be approximately $15 \%$ of that of the crude eyestalk extracts in M-saline (Fig. 6).

\section{The effect of eyestalk extract from $P$. vanname $i$}

Injected eyestalk extract from $P$. vannamei (PVE) in $\mathrm{M}$-saline at 1 and 2 eyestalk equivalent concentrations produced an increase in haemolymph vitellogenin at 12 and $24 \mathrm{~h} \mathrm{PI}$, an effect similar to that of the control group receiving $\mathrm{M}$-saline. Hence the extracts did not show any significant difference on the haemolymph vitellogenin levels from the saline treatment (Fig. 7 and Table 1).

High-purity vitellin from the gravid ovary of 


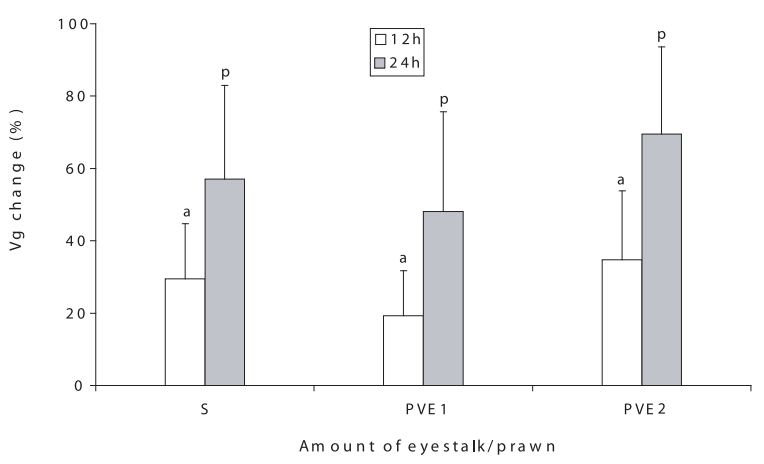

Fig. 7 The effects of eyestalk extract from P. vannamei on the change in haemolymph vitellogenin levels at $12 \mathrm{~h}$ (white histogram) and $24 \mathrm{~h}$ (grey histogram) $(n=10) . S=$ saline and PVE $=$ crude eyestalk extract of $P$. vannamei.

M. rosenbergii was isolated with simple centrifugation and used for the production of MAbs that could bind to both subunits of vitellin and its precursor vitellogenin in the haemolymph. Vitellogenin is immunologically and electrophoretically indistinguishable from vitellin, as was demonstrated in several decapod species, including $M$. rosenbergii ${ }^{32,33}$, P. monodon ${ }^{29,34}$ and Litopenaeus merguiensis. Hence anti-vitellin antiserum and vitellin-specific antibodies could be used for the development of a quantitative analysis of vitellogenin in different forms of immunoassays in several decapoda species ${ }^{11,32,35,36}$. In $M$. rosenbergii, the main subunits of vitellin and vitellogenin are 89 and $100 \mathrm{kDa}$ proteins, respectively; however, in haemolymph a $170 \mathrm{kDa}$ protein was recognized by the MAb specific to the $100 \mathrm{kDa}$ subunit but not with the MAb specific to the $89 \mathrm{kDa}$ subunit. The $170 \mathrm{kDa}$ protein is suggested to be a precursor of the $100 \mathrm{kDa}$ subunit because the amino acid sequences at the $\mathrm{N}$-terminal end of both proteins are identical ${ }^{32}$.

The parallelism between vitellin standard curved and diluted female haemolymph from developing $M$. rosenbergii in competitive ELISA and non-parallelism with the male haemolymph were similar to the results obtained from the ELISA from various studies $11,32,34,35$.

The combination of the two MAbs specific to each subunit of vitellin and vitellogenin in the development of an indirect competitive ELISA yields high-fidelity results, as the intra- assay and inter-assay variations were in the acceptable ranges. Although the sensitivity was not noticeably different from using a single MAb, the combination of two MAbs was used to ensure the detection of all vitellogenin subunits present in the haemolymph.
The correlation between haemolymph vitellogenin levels and the ovarian index (OI) at various stages of ovarian development was difficult to elucidate because the variation of OI and haemolymph vitellogenin levels at each stage of ovarian development in individual prawns was very high ${ }^{10,11,35,37}$. However, the relationship between haemolymph vitellogenin levels and the stages of ovarian development was clearly observed. The haemolymph vitellogenin levels were elevated and highly fluctuated among individual during vitellogenesis in the ovary and sharply dropped when the ovaries were mature and ready to spawn $^{10,11}$; this correlated with the mRNA levels in the ovary and hepatopancreas, which are high during vitellogenesis, remain high until final maturation, and then decrease after oviposition. The sinus gland extract could reduce the vitellin mRNA expression by over $90 \%$ in the Marsupenaeus japonicus ovarian fragments in vitro ${ }^{20}$. Hence the ovarian vitellogenesis stage would be a suitable stage for the determination of the inhibitory effect of VIH because the change in vitellogenin mRNA expression would correlate the change in haemolymph vitellogenin levels as well ${ }^{24}$.

In our in vivo assays, the crude eyestalk extract in M-saline at sufficient amounts (equivalent to $1 / 2$ eyestalk) and the acetic methanol eyestalk extract (equivalent to 3 eyestalks) could effectively reduce the haemolymph vitellogenin levels in eye-ablated $M$. rosenbergii undergoing active ovarian development. The inhibitory activity of the extract was preserved (approximately 15\%) in the acetic methanol extraction and partially purified in the $\mathrm{C}_{18}$ cartridge. Increasing the amounts of eyestalk extract did not cause a significant increase in the inhibitory effect of the haemolymph vitellogenin levels. The reduction of the eyestalk extract concentration below the threshold levels ( $1 / 4$ eyestalk crude extract equivalent in saline) demonstrated an increase in vitellogenin levels similar to that produced by the control $\mathrm{M}$-saline injection. Injection of eyestalks extracted with methanol acetic acid produced a response similar to the saline injection in 6 and 7 prawns at 12 and $24 \mathrm{~h}$ PI, respectively, while 4 prawns at $12 \mathrm{~h}$ PI and 3 prawns at $24 \mathrm{~h}$ PI responded similarly to the prawns that were injected with 3 eyestalk equivalents. The response to inhibitory factors seems to be required sufficient concentration to respond and slightly less concentration would not generate the response at all. In this case, the development of the ova in the ovary should be synchronized, as numerous ova are released at each spawning period. A threshold for stimulation would therefore need to control these processes rather than a graded dose response pattern. 
It is quite interesting that the eyestalk extract from $P$. vannamei was not able to reduce haemolymph vitellogenin in $M$. rosenbergii. The ineffective heterologous assay confirmed the evidence that the inhibitory effects observed in this study were not due to nonspecific inhibition as a result of the high protein content in the extract. It has been demonstrated that the eyestalk extract from $M$. rosenbergii has no effect on the change of haemolymph vitellogenin levels in eye-ablated $P$. monodon, whereas the eyestalk extract from $P$. monodon and the closely related species Metapenaeus affinis has a significant effect ${ }^{11}$. Similar evidence from an in vitro assay showed that a high concentration of recombinant $H$. americanus VIH could partially reduce vitellin mRNA expression in the Marsupenaeus japonicus ovarian fragment ${ }^{20}$. The use of the heterologous bioassay with an evolutionarily distant species was therefore not as suitable as a homologous or closely related species bioassay.

The mechanisms of VIH inhibition of ovarian development are not yet clear. One observation in this study is the VIH-induced reduction of vitellogenin synthesis and its release into circulation. Vincent et $\mathrm{al}^{36}$ demonstrated similar evidence that two RPHPLC purified fractions caused a gradual reduction of haemolymph vitellogenin concentrations in unilateral eye-ablated $P$. monodon within $8 \mathrm{~h}$. It has been found in $P$. monodon and several decapod crustacean species that there are many forms of CHH-GIH-MIH related hormones, such as 5 forms of crustacean hyperglycaemic hormones ${ }^{38}$ and two to three forms of moltinhibiting hormones ${ }^{39}$.

An in vivo VIH inhibition assay has been performed by the incorporation of radioactive-labelled $\left[{ }^{35} \mathrm{~S}\right]$ methionine into vitellin in the ovary of Procambarus clarkii. The inhibiting activity reached its peak effect between 12 and $24 \mathrm{~h}$ following sinus gland extract injection ${ }^{40}$. This study indicated that the inhibitory effect of eyestalk extract on protein synthesis in this species is slow and was similar to our findings on the reduction in haemolymph vitellogenin levels.

In this experiment in eye-ablated $M$. rosenbergii with a developing ovary, the levels of haemolymph vitellogenin at the beginning of the experiment were highly variable (less than $0.2 \mathrm{mg} / \mathrm{ml}$ to over $3 \mathrm{mg} / \mathrm{ml}$ ). The different vitellogenin levels at the beginning of the experiment affect the relative percentage change of vitellogenin after treatment. If the vitellogenin levels at the beginning were low, a slight change would produce a relatively high percentage change compared to the prawns with higher vitellogenin levels at the beginning of the experiment. If a sufficient amount of eyestalk was used, a clear inhibitory effect was observed.

In conclusion, MAbs specific to both subunits of vitellogenin and vitellin were generated and used for the development of a competitive ELISA for the quantitative analysis of vitellogenin levels in the haemolymph for an in vivo assay of VIH activity. The application of homologs of VIH using eyestalk extract either in M-saline or in methanol acetic acid caused a reduction in haemolymph vitellogenin levels in eyeablated $M$. rosenbergii with developing ovaries, and the response was not dose dependent. The minimal amount of eyestalk extract that demonstrated a clear inhibitory effect was the amount that was equivalent to $1 / 2$ eyestalk in M-saline or 3 eyestalks in a methanol acetic acid extraction. In contrast, the application of M-saline or heterologous eyestalk extract (P. vannamei) in $\mathrm{M}$-saline did not produce a reduction in haemolymph vitellogenin levels. The change in haemolymph vitellogenin levels could therefore be used for monitoring the inhibitory effect of VIH and other related hormones that may produce similar effects.

Acknowledgements: This study was supported by the Srinakharinwirot University Research Fund, Srinakharinwirot University Research Division and the Office of Commission on Higher Education, Thailand.

\section{REFERENCES}

1. Eastman-Reks SB, Fingerman M (1985) In vitro synthesis of vitellin by the ovary of the fiddler crab, Uca pugilator. J Exp Zool 233, 111-6.

2. Yano I, Chinzei Y (1987) Ovary is the site of vitellogenin synthesis in kuruma prawn, Penaeus japonicus. Comp Biochem Physiol B 86, 213-8.

3. Lee CY, Watson RD (1995) In vitro study of vitellogenesis in the blue crab (Callinectes sapidus): Site and control of vitellin synthesis. J Exp Zool 271, 364-72.

4. Tseng D, Chen Y, Kou G, Lo C, Kou C (2001) Hepatopancreas is the extraovarian site of vitellogenin synthesis in black tiger shrimp, Penaeus monodon. Comp Biochem Physiol A 129, 909-17.

5. Tsang WS, Quackenbush LS, Chow BKC, Tiu SHK, He JG, Chan SM (2003) Organization of the shrimp vitellogenin gene: evidence of multiple genes and tissue specific expression by the ovary and hepatopancreas. Gene 303, 99-109.

6. Warrier S, Subramoniam T (2002) Receptor-mediated yolk protein uptake in the crab Scylla serrata: crustacean vitellogenin receptor recognizes related mammalian serum lipoproteins. Mol Reprod Dev 61, 536-48.

7. Wilder MN, Subramoniam T, Aida K (2002) Yolk proteins of crustacea. In: Raikhel AS, Sappington TW (eds) Reproductive Biology of Invertebrates Vol. XII: 
Recent Progress in Vitellogenisis, Science Publishers Inc, Enfield, NH, pp 131-74.

8. Tsukimura B (2001) Crustacean vitellogenesis: Its role in oocyte development. Am Zool 41, 465-76.

9. Chang CF, Shih TW (1995) Reproductive cycle of ovarian development and vitellogenin profiles in the freshwater prawns, Macrobrachium rosenbergii. Invertebr Reprod Dev 27, 11-20.

10. Lee FY, Chang CF (1997) The concentrations of vitellogenin (vitellin) and protein in hemolymph, ovary and hepatopancreas in different ovarian stages of the fresh water prawn, Macrobrachium rosenbergii. Comp Biochem Physiol A 117, 439-43.

11. Longyant S, Sithigorngul P, Sithigorngul W, Chaivisuthangkura P, Thammapalerd N, Menasveta P (2004) The effect of eyestalk homogenate on haemolymph vitellogenin levels in the black tiger prawn Penaeus monodon. Invertebr Reprod Dev 45, 91-100.

12. Huberman A (2000) Shrimp endocrinology. A review. Aquaculture 191, 191-208.

13. Hopkins PM (2012) The eyes have it: A brief history of crustacean neuroendocrinology. Gen Comp Endocrinol 175, 357-66.

14. Soyez D, Le Caer JP, Noel PY, Rossier J (1991) Primary structure of two isoforms of the vitellogenesis inhibiting hormone from the lobster Homarus americanus. Neuropeptides 20, 25-32.

15. Grève P, Sorokine O, Berges T, Lacombe C, Van Dorsselaer A, Martin G (1999) Isolation and amino acid sequence of a peptide with vitellogenesis inhibiting activity from the terrestrial isopod Armadillidium vulgare (Crustacea). Gen Comp Endocrinol 115, 406-14.

16. Edomi P, Azzoni E, Mettulio R, Pandolfelli N, Ferrero EA, Giulianini PG (2002) Gonad-inhibiting hormone of the Norway lobster (Nephrops norvegicus): cDNA cloning, expression, recombinant protein production, and immunolocalization. Gene 284, 93-112.

17. Gu PL, Tobe SS, Chow BKC, Chu KH, He JG, Chan SM (2002) Characterization of an additional molt inhibiting hormone-like neuropeptide from the shrimp Metapenaeus ensis. Peptides 23, 1875-83.

18. Yang WJ, Rao KR (2001) Cloning of precursors for two MIH/VIH-related peptides in the prawn, Macrobrachium rosenbergii. Biochem Biophys Res Comm 289, 407-13.

19. De Kleijn DPV, Sleutels FJGT, Martens GJM, Van Herp F (1994) Cloning and expression of mRNA encoding prepro-gonad-inhibiting hormone $(\mathrm{GIH})$ in the lobster Homarus americanus. FEBS Lett 353, 255-8.

20. Ohira T, Okumura T, Suzuki M, Yajima Y, Tsutsui N, Wilder MN, Nagasawa H (2006) Production and characterization of recombinant vitellogenesis-inhibiting hormone from the American lobster Homarus americanus. Peptides 27, 1251-8.

21. Treerattrakool S, Panyim S, Chan SM, Withyachumnarnkul B, Udomkit A (2008) Molecular characterization of gonad-inhibiting hormone of Penaeus monodon and elucidation of its inhibitory role in vitellogenin expression by RNA interference. FEBS J 275, 970-80.

22. Treerattrakool S, Chartthai C, Phromma-in N, Panyim S, Udomkit A (2013) Silencing of gonad-inhibiting hormone gene expression in Penaeus monodon by feeding with GIH dsRNA-enriched Artemia. Aquaculture 404-405, 116-21.

23. Treerattrakool S, Panyim S, Udomkit A (2011) Induction of ovarian maturation and spawning in Penaeus monodon broodstock by double-stranded RNA. Mar Biotechnol 13, 163-9.

24. Jayasankar V, Tsutsui N, Jasmani S, Saido-Sakanaka H, Yang WJ, Okuno A, Hien TTT, Aida K, et al (2002) Dynamics of vitellogenin mRNA expression and changes in hemolymph vitellogenin levels during ovarian maturation in the giant freshwater prawn $\mathrm{Mac}$ robrachium rosenbergii. J Exp Zool 293, 675-82.

25. Bradford MM (1976) A rapid and sensitive method for the quantitation of microgram quantities of protein utilizing the principle of protein-dye binding. Anal Biochem 72, 248-54.

26. Mosmann TR, Baumal R, Williamson AR (1979) Mutations affecting immunoglobulin light chain secretion by myeloma cells. I: Functional analysis by cell fusion. Eur J Immunol 9, 511-6.

27. Eshhar Z (1985) Monoclonal antibody strategy and techniques. In: Springer TA (ed) Hybridoma Technology in the Biosciences and Medicine, Plenum Press, New York, pp 1-42.

28. Johnson DA, Gautsch JW, Sportsman JR, Elder JH (1984) Improved technique utilizing nonfat dry milk for analysis of proteins and nucleic acids transferred to nitrocellulose. Gene Anal Tech 1, 3-8.

29. Longyant S, Sithigorngul P, Thammapalerd N, Sithigorngul W, Menasveta P (2000) Characterization of vitellin and vitellogenin of giant tiger prawn $\mathrm{Pe}$ naeus monodon using monoclonal antibodies specific to vitellin subunits. Invertebr Reprod Dev 37, 211-21.

30. Nagamine C, Knight AW, Maggenti A, Paxman P (1980) Effects of androgenic gland ablation on male primary and secondary sexual characteristics in the Malaysian prawn, Macrobrachium rosenbergii (de Man) (Decapoda, Palaemonidae), with first evidence of induced feminization in a nonhermaphroditic decapod. Gen Comp Endocrinol 41, 423-41.

31. Sithigorngul W, Jaideechoey S, Saraithongkum W, Longyant S, Sithigorngul P (1999) Purification and characterization of an isoform of crustacean hyperglycemic hormone from the eyestalk of Macrobrachium rosenbergii. J Exp Zool 284, 217-24.

32. Lee FY, Shih TW, Chang CF (1997) Isolation and characterization of the female-specific protein (vitellogenin) in mature female haemolymph of the freshwater prawn, Macrobrachium rosenbergii: comparison with ovarian vitellin. Gen Comp Endocrinol 108, 406-15.

33. Chang CF, Shih TW, Hong HH (1993) Purification and characterization of vitellin from the mature ovaries 
of prawn, Macrobrachium rosenbergii. Comp Biochem Physiol B 105, 609-15.

34. Quinitio ET, Hara A, Yamaguchi K, Fuji A (1990) Isolation and characterization of vitellin from the ovary of Penaeus monodon. Invertebr Reprod Dev 17, 221-7.

35. Tsukimura B, Bender JS, Linder CJ (2000) Development of an anti-vitellin ELISA for the assessment of reproduction in the ridgeback shrimp, Sicyonia ingentis. Comp Biochem Physiol A 127, 215-24.

36. Vincent SG, Keller R, Subramoniam T (2001) Development of vitellin ELISA, an in vivo bioassay, and identification of two vitellogenesis-inhibiting hormones of the tiger shrimp Penaeus monodon. Mar Biotechnol 3, $561-71$.

37. Jasmani S, Kawazoe I, Shih TW, Suzuki Y, Aida K (2000) Hemolymph vitellogenin levels during ovarian development in the kuruma prawn Penaeus japonicus. Fish Sci 66, 535-9.

38. Davey ML, Hall MR, Willis RH, Oliver RW, Thurn MJ, Wilson KJ (2000) Five crustacean hyperglycemic family hormones of Penaeus monodon: complementary DNA sequence and identification in single sinus glands by electrospray ionization-Fourier transform mass spectrometry. Mar Biotechnol 2, 80-91.

39. Nakatsuji T, Lee CY, Watson RD (2009) Crustacean molt-inhibiting hormone: structure, function, and cellular mode of action. Comp Biochem Physiol A 152, 139-48.

40. Chaves AR (2000) Effect of x-organ sinus gland extract on $\left[{ }^{35} \mathrm{~S}\right]$ methionine incorporation to the ovary of the red swamp crawfish Procambarus clarkii. Comp Biochem Physiol A 126, 407-13. 